\title{
Big Data as a Customer Management Relationship Tool
}

\author{
Leonardo de Lima Francisco ${ }^{1}$, Wenderson Fernandes Moura ${ }^{1}$, Leandro Ricardo Sabino ${ }^{1}$, Valdeci Ferreira dos Santos ${ }^{1}$ \\ \& Rodrigo Barreto Esquarcio ${ }^{1}$ \\ ${ }^{1}$ FUMEC University, Belo Horizonte, Minas Gerais, Brazil \\ Correspondence: Wenderson Fernandes Moura, FUMEC University, Belo Horizonte, Minas Gerais, Brazil, Av. \\ Afonso Pena, 3880 - Centro, Belo Horizonte - MG, 30130-000, Brazil. Tel: 55-31-99126-2030.
}

Received: October 24, 2016

Accepted: November 8, 2016

Online Published: November 13, 2016

doi:10.5430/ijba.v7n6p91

URL: http://dx.doi.org/10.5430/ijba.v7n6p91

\begin{abstract}
Considering the growth of globalization and the constant technological innovations, fields such as Internet and Social Networks have been brought into relevance - if not into prevalence - with organizations' attempts of better understanding their customers - having always preserving their business and becoming more competitive to the eye of the market as their main challenges. In this context, the increased data volume and speed naturally demands organizations to develop processes and mechanisms to analyze and interpret data for decision making. The objective of this article - which is based on secondary data research and theoretical comparison among the authors of the themes, analysis of key-concept and case studies - is to introduce the relation between a data compilation tool, named Big Data, and its relations with marketing as a customer relations vehicle, in a quest for adding value to business.
\end{abstract}

Keywords: big data, CRM, relationship marketing

\section{Introduction}

Bearing in mind all the globalization processes of human relations taking place in every aspect and the constant technological evolution connected to those processes (such as the use and diffusion of the Internet and the, so-called, Social Networks) nowadays, the challenges faced by organizations, market-wise, are attracting customers, keeping the business attractive and making it more competitive in its own field. In this context, such organizations will some time have to use their own data, data sets from external sources with the purpose of assessing and understanding their customers' preferences to be able to compete or merely to survive. When they get to know what their customers value the most, what their payment methods of preference and what their demands for the future are, etc. the organizations become able to trace strategies which may improve their performance and their competitive edge.

Besides, with the ever faster emergence of new information technologies and the escalade of the usage of ever faster and more practical portable devices, large amounts of data flow in significant speed and volumes, which may - from the organization's viewpoint - bring cost reduction and relevant improvement in the time needed to perform a mapping or computing task or offers of new customers, products and services (Taurion, p. 5, 2013).

This is how Relationship Marketing came up, where solid economic, technical and social connections are established between organizations and customers and its action is based on the identification of how such relationships are established and how they can affect marketing activities' success in a company (Kotler \& Keller, 2012). In the current context, organizations may use Big Data to support Relationship Marketing as an extraction, interpretation and data analysis tool to produce customer information and to support decision making within the organization. Big Data is a provision in technology that can help understand customers, develop products, services and market, besides improve operational effectiveness and adjust market demand forecasts (Kotler \& Keller, 2012; Isaca, 2013; Davenport \& Dyché, 2013).

The present work aims to introduce the understanding of referential authors in the field, besides bringing up considerations on the use of the integration of Big Data and marketing as a tool and a strategy to improve customer relationship, thus adding value to business by answering the following question: what is the importance of the relation between Big Data and marketing for the improvement of the customer relationship? 


\section{Methodology}

Methodologically, this work is based on published studies from some conceptual understandings and practical cases of researches performed in company organizations which used Big Data and their relations with relationship marketing.

It is an exploratory-descriptive article. Exploratory because its objective is to build knowledge by means of selection and analysis of scientific works published in journals and indexed in the database based on a specific theme (Vieira, 2002). To discuss and analyze the work, an information, data and understandings study on survey already produced which references to Big Data and to customer relationship marketing was adopted as a method in order to allow for reflection and analysis on the conceptual and practical issues on the themes (Richardson, 2008; Gil, 2008).

Based on the literature available, the present work discusses concepts referring to relationship marketing, Big Data and Customer Relationship Management - CRM. What is intended here is a succinct discussion on the theme by assessing cases already published on the use of Big Data by organizations which successfully achieved by doing so.

\section{Theoretical Foundation}

\subsection{Big Data}

In the current business setting, organizations looking for some competitive differential seek to optimize their resources, aiming at best ways to work at the lowest possible cost. Based on that need, they resource to Information Technology products for effective and efficient storage and access in a information in a well-structured way which enables them to know their suppliers, competitors and customers, other than only their consumption trends (Henriques \& Da Costa, 2014). Thus, understanding information involving organizations is capital for the success of the enterprise. The several features of information, as well as the diverse ways to classify them, are decisive when choosing the tools which shall be used for their treatment.

According to Novo and Neves (2013), Big Data is an evolutionary method for traditional data assessment and analysis, which predicts a fast and increasing demand of assessment for the high volume of data from several sources. To Lohr (2012), Big Data, besides being a marketing term, is a technological trend that opens the door to a new approach to understand the world and simplifies decision-making.

Henrique and Da Costa (2014) characterize Big Data as a technical and marketing term which integrates capital information to add value to businesses. That term is about a large volume of data from sources as web analytics, social media, graphic media, sponsored links, sociodemographic data, among others, and which does not depend on the size of the organization. Data volume, speed, truthfulness and variety are relevant inputs, and so is the clear possibility of benefits and real profits which enable its utilization, i.e., the value or data.

However, the large availability of data and information, added to the advancement of technology, show that this tool's greatest challenge is not the technological resource, but the human resource, minding that guiding the need of information to the needs of the organization keeps being the managers' task. Then, to use the benefits of Big Data it is considered of utmost importance understanding one's own business, and knowing what type of information is important for that business to develop (Henriques \& Da Costa, 2014; Feijó, 2013). It is also necessary to emphasize the importance of data safety and data privacy for all parties involved, as well as all parties involved must be aware of the implications relative to storing and cross-analyzing large amount of confidential data (Isaca, 2013).

Aiming to reach all the benefits of Big Data, according to McAfee and Brynjolfsson (2012), companies must effectively manage the transformation process. The challenges in this process are:

- Leadership: people establishing goals to be achieved manage to involve and influence the work team in the search of desired results by means of a decision-making process. That means, the existence of leaders in the organization operates integration and guides people's efforts to achieve excellence.

- New Talents Management: to work with large amounts of information it is capital hiring and keeping qualified professionals to lead and to manage by using tools and techniques.

- Technology: tools available to deal with data volume, speed and variety have improved very much in the latest years and should be always kept up-to-date and in good working conditions.

- Decision-Making: for effective decision-making, data must be known and assessed to be used the right way. Data-based decisions tend to be better decisions.

- Organization Culture: organizational challenges are huge, but the concern with privacy is the most significant of them all. 
The objective and most important reward from Big Data are the ability of analyzing diverse sources and new types of data, and not the management of large bulks of data (Davenport \& Dyché, 2013). Big Data can add value to organizations by finding patterns and relationships among data- located on the web, in data warehouses, on Facebook, on Twitter, in YouTube videos and other sources, regardless of the business segment. Companies that manage using Big Data and keep innovative in its use will be able to produce competitive advantages along time and to interact more effectively with customer relationship marketing (Taurin, 2013).

\subsection{Customer Relationship}

Organizations constantly seek to differentiate their products or services (offer) to their competitors' market. From the moment a company becomes successful, other organizations will copy that offer and offer short-term competitive advantages. Thus, companies need to rethink their strategies, developing new features and benefits with the purpose of grasping the attention and interest of ever more demanding consumers - who always seek for lower prices, good quality and satisfaction. And that is why it becomes important to establish a good relationship with already loyal customers using, above all, marketing tools (Kotler \& Keller, 2012). Relationship marketing is a tool used by organizations to manage the interaction with consumers by means of a set of techniques, tools and processes applied continuously with the goal of identifying the customer and promoting a satisfactory relation between the parties (Demo \& Guanabara, 2015; Stone \& Woodcock, 2009; Soares \& Monteiro, 2015).

Relationship marketing first appeared in the 80 's by changing the focus from transactional marketing to relational marketing, aiming to customer participation with the purpose of producing satisfaction and trust (Soares \& Monteiro, 2015; Morgan \& Hunt, 1994). In a highly competitive scenario and one with strong competition, knowing the customer becomes a need for organizations and relationship marketing is a tool with great relevance so that organizations may bring closer the customer (Barreto, Crescitelli \& Figueiredo, 2015).

Demo (et. al. 2015) presents relationship marketing as a strategy where the consumer is placed in the spotlight, breaking the paradigm of marketing as a manipulator and entering an actual involvement with the customer as a virtual leading figure in the process. This way, relationship marketing must always be as lasting as possible, aiming at bringing profit as it increments customer permanence, satisfaction and loyalty, besides compromise and trust (Morgan \& Hunt, 1994).

Customer Relationship Management - CRM - first appeared in the 90's from the evolution of studies and researches on relationship marketing with the goal of providing loyalty and profitability to companies and adding value to their customers (Agrawal, 2004; Freitas, Cunico \& Pedron, 2014). CRM is a tool to understand better the target audience of an organization through information collected or made available by customers themselves (Demo et. al., 2015).

CRM consists of using software to analyze customer data collected (either internally to or externally from the company) and deeply analyzed with the purpose of creating and developing a reliable and harmonious relationship with those customers. Based on the information collected, CRM can produce, create and offer goods or services the customer wants to consume, even with the possibility of anticipating their needs (Freitas, Cunico \& Pedron, 2014).

Implementation of CRM into the organizations is of utmost importance as a competitiveness strategy. However, the development and utilization of programs to manage that relation requires involvement and technical knowledge of the company so that tools can be properly used, besides resources and capacity to manage everything that is produced in that process (Maklan \& Knox, 2009).

With the current technological advances and the large amount of information stored and available (by clouds, for example, that surpass the ability to capture, manage, store and analyze specific database tools on the Internet), using Big Data as a tool to create and develop CRM becomes necessary and indispensable for companies to perform an efficient and effective management to build a good relationship with their consumers. This way, a CRM work would support relationship marketing in order not only to produce relevant information for business decision-making, but also to produce new management policies for that information and how to make them more accessible, useful and safe.

\subsection{Relationship between Big Data and Client Relationship Marketing}

Advances on analytic techniques, on information technology, on the technology cost reduction and on the attempts of capturing and retaining customers are boosting the growing the use of Big Data. Large organizations have used that technology to raise awareness that may lead to a competitive edge. The relationship between relationship marketing and Big Data may allow companies to relate with clients more effectively, creating opportunities for automation of relationship processes and to manage useful business information. In this context, CRM and other technologies may be used in several business segments and cause more interactivity among people with possibilities of information 
sharing in favor of the creation and definition of customer relation strategies (Taurion, 2013; Davenport \& Dyché; 2013; Waller \& Fawcett; 2013; Novo \& Neves, 2013).

A big company such as Macy's - a giant worldwide retailer - use high quality technology to know and service their customers and is strongly oriented to the wishes and needs of their customers. Through the use of Big Data and the implementation of customer relationship actions - which involved personalization and segmented advertisement Macy's managed to integrate the existing systems in their organization and cut costs with informatics equipment purchasing in up to $70 \%$. Companies in diverse segments use the link between Big Data and marketing to know and service their clients, here are some of them: Bank of America, MasterCard, IBM, Intel, Wal-Mart, NetShoes, among others (Davenport \& Dyché; 2013; Mcafee \& Brynjolfsson, 2012).

Bulygo (2013) reports that Netflix performs daily studies of their customers through the use of Big Data with the purpose of providing and suggesting them their products and services. Starbucks company, the worldwide known by using Big Data with effective profit in their businesses and in the development of strategies to retain their customers, uses this tool in order to be more assertive in the process of opening new units always following regional demands (Rijmenam, 2015).

According to research by Pricewaterhouse Coopers in 2013, managers believe that Big Data is much more than only data compilation; they think Big Data actually represents a new way to manage and know customers. It is a decision-making process based on data and on new types of data-enriched products and services which have been given new perception from customers, products and markets.

\section{Final Considerations}

After this exploratory research came to its end we could infer that, based on Big Data, all business sectors are affected, in higher or lower degree, mainly if we bear in mind that the technology which makes this tool operational is available to everyone - through flexible arrangements of allocation of resources and cloud computing - thus enabling the creation of Big Data scenarios for the definition of strategies and decision-making in virtually every possible organizational scenario.

Based on the authors' understandings seen in this work we believe that the differential Big Data brings to organizations relays on the sophistication and maturity managing information, and on how that information may be used to improve customer relationship and add value to the business. To Waller and Fawcett (2013) an appropriate exploration of Big Data can help improve organizational development but for that it is capital changing the companies' culture and their provision. That means to say that it is necessary to employ some effort for the transformation and assessment of a large volume of informational data which can add value to the business in day-by-day activities.

Based on the joint utilization of Big Data and relationship marketing companies are able to modify information data and knowledge and, by consequence, increase competitiveness, add value to the business and boost customer loyalty relations. It is important to highlight that information obtained must be used as to ensure the aspects: privacy, ethics and legal factors.

Understanding customers' needs and desires is not always an easy task. Some consumers present demands upon which they have no awareness or cannot articulate them competently enough (Kotler, 2000). To identify those customers' desires, even before they are aware themselves, the organization should consolidate a relationship based on data trustworthiness, at the same time that organization follows up market evolution.

Limitations of this study point to the lack of national researches relating the constructs "relationship marketing" and "Big Data", and to how that relation could contribute for organizations in general; besides the lack of comparative data and empirical evidence and theories to provide critical support, the usability and awareness of Big Data in the decision-making process.

For future works on Big Data we suggest scientific researches to be developed related to business intelligence with focus on social networks and on the competitive edge that can be reached by using Big Data. It is of major importance that those studies proposed should focus on other business administration theories (marketing, organizational and contingency behavior, etc.)

\section{References}

Agrawal, M. L. (2004). Customer Relationship Management - CRM \& corporate renaissance. Journal of Services Research, 3(2), 1-23.

Barreto, I. F., Crescitelli, E., \& Figueiredo, J. C. B. (2015). Resultados de Marketing de Relacionamento: proposição de modelo por meio de mapeamento cognitivo. Revista Brasileira de Gestão de Negócios, 17(58), 1371-1389. 
Bulygo, Z. (2013). How Netflix Uses Analytics To Select Movies, Create Content, and Make Multimillion Dollar Decisions. Kissmetrics Blog. Retrieved July 18, 2016, from https://blog.kissmetrics.com/how-netflix-uses-analytics/

Davenport, T. H., \& Dyché, J. (2013). Big Data in Big Companies. Thomas H. Davenport and SAS Institute Inc. Retrieved July 13, 2016, from https://www.sas.com/resources/asset/Big-Data-in-Big-Companies.pdf

Demo, et al. (2015). Marketing de relacionamento (CRM): estado da arte, revisão bibliométrica da produção nacional de primeira linha, institucionalização da pesquisa no Brasil e agenda de pesquisa. RAM - Revista de Administração Mackenzie, 16(5), 127-160.

Demo, G., \& Guanabara, M. (2015). Marketing de relacionamento com a Apple: O papel do julgamento e significado de produto na escolha do iPhone. Revista Eletrônica de Administração, 21(1), 170-199.

Feijó, B. V. (2013). A Revolução dos Dados. São Paulo: Revista Exame PME - Pequenas e Médias Empresas, 30-43.

Freitas, W. R. S., Cunico, E., \& Pedron, C. D. (2015). Marketing de Relacionamento e Customer Relationship Management: uma análise da produção científica nacional à luz do componente recursos humanos. RAC Revista de Ciências da Administração. 17(42), 9-21. https:/doi.org/10.5007/2175-8077.2015v17n42p9

Gil, A. C. (2008). Métodos e Técnicas de Pesquisa Social. São Paulo: Atlas.

Henriques, D. A., \& Da Costa, H. R. (2014). Big Data: como utilizar a extraordinária quantidade de informações coletadas por novas tecnologias para obter vantagens competitivas. Revista Pensar, 3(1). Retrieved July 3, 2016, from http://revistapensar.com.br/tecnologia/pasta_upload/artigos/a72.pdf

Isaca. (2013). Big Data: impacts and benefits. Retrieved July 19, 2016, from $\mathrm{http}: / / \mathrm{www}$. infosecurityeurope.com/_novadocuments/48835?v=635307736120470000

Kotler, P. (2000). Administração de Marketing. São Paulo: Prentice Hall.

Kotler, P., \& Keller, K. (2012). Administração de marketing (14 ed.). São Paulo: Pearson.

Lohr, S. (2012). The age of Big Data. New York Times. Retrieved July 3, 2016, from http://www.nytimes.com/2012/02/12/sunday-review/big-datas-impact-in-the-world.html?_r=0

Maklan, S., \& Knox, S. (2009). Dynamic Capabilities: the missing link in CRM investments. European Journal of Marketing, 43(11/12), 1392-1410. https:/doi.org/10.1108/03090560910989957

Mcafee, A., \& Brynjolfsson, E. (2012). Big Data: the management revolution. Harvard Business Review, 59-68.

Morgan, R. M., \& Hunt, S. D. (1994). The commitment-trust theory of relationship marketing. Journal of Marketing, 58, 20-38. https:/doi.org/10.2307/1252308

Novo, R., \& Neves, J. M. S. (2013). Inovação na inteligência analítica por meio do Big Data: características de diferenciação da abordagem tradicional. Workshop de Pós-Graduação e Pesquisa do Centro Paula Souza, São Paulo, 8, 32-44. Retrieved July 3, 2016, from http://www.cps.sp.gov.br/pos-graduacao/workshop-de-pos-graduacao-e-pesquisa/008-workshop2013/trabalhos/ desenvolvimento_de_tecnologia_e_sistemas/121191_32_44_FINAL.pdf

Pricewaterhouse Coopers - PWC. (2013). Capitalizing on the promise of Big Data. 1-8. Retrieved July 10, 2016, from https://www.pwc.com/us/en/increasing-it-effectiveness/assets/capitalizing-on-the-promise-of-big-data.pdf

Richardson, R. J. (2008). Pesquisa social: métodos e técnicas (3. ed.). São Paulo: Atlas.

Rijmenam, M. (2015). Starbucks, The World Largest Coffee Shop, Grinds A Lot Of Data Datafloq. Retrieved July 18, 2016, from https://datafloq.com/read/world-largest-coffee-shopstarbucks-grinds-lot-dat/440

Soares, F., \& Monteiro, P. R. R. (2015). Marketing digital e marketing de relacionamento: interação e engajamento como determinantes do crescimento de páginas do Facebook. Navus - Revista de Gestão e Tecnologia, 5(3), $42-59$.

Stone, M., \& Woodcock, N. (2009). Marketing de Relacionamento. São Paulo: Littera Mundi.

Taurion, C. (2013). O estágio atual do Big Data no Brasil. Revista Power Channel, 20, 5-7. Retrieved July 13, 2016, from http://www.powerchannel.com.br/2013/06/03/cezar-taurion-o-estagio-atual-do-big-data-no-brasil/

Vieira, V. A. (2002). As tipologias, variações e características da pesquisa de marketing. Revista da FAE, Curitiba, $5(1), 61-70$.

Waller, M. A., \& Fawcett (2013). Click Here for a Data Scientist: Big Data, Predictive Analytics, and Theory Development in the Era of a Maker Movement Supply Chain. Journal of Business Logistics, 34(4), 249-252. 